\title{
Indigenous Knowledge and Bioindicators of Toxicity of Non-Timber Forest Products in the Democratic Republic of Congo (DRC)
}

\author{
Remy M.K. Vala \\ Department of Chemistry, Vaal University of Technology, \\ P. O. Box X021, Vanderbijlpark 1900, Republic of South Africa \\ Email:mavularemy@gmail.com
}

\section{Doi:10.5901/mjss.2014.v5n15p386}

\begin{abstract}
This study aimed to understand the indigenous knowledge used by some rural communities in the DRC for the collection of non-timber forest products. A "general interview guide approach" was used for collecting information from each of the randomly selected interviewees (women) of different ages and backgrounds (in Kinshasa, the capital city of the DRC, Central Africa). Results showed that indigenous knowledge used for the collection of non-timber forest products, in the DRC, is essentially based on "the presence of living organisms found on or around, or eating the non-timber forest products or their derivatives". The living organisms, called bio-indicators, were found to be birds, monkeys, millipedes, caterpillars, locusts and free range chickens. The interviewees strongly recommended strict identification of these living organisms as indigenous knowledge skill received or taught to avoid intoxication from naturally available resources.
\end{abstract}

Keywords: Indigenous knowledge, Bioindicators, Non-timber forest products, Intoxication, DRC

\section{Introduction}

Non-timber forest products are defined by the Canadian Forest Service (2007) as "Any commodity obtained from the forest that does not necessitate harvesting trees. It includes game animals, nuts and seeds, mushrooms, foliage, medicinal plants, fuel wood, etc." Since the appearance of life on earth, non-timber forest products have been of a particular need for the survival of humans as well as animals. Many rural communities still make extensive use of nontimber forest products for their living. Although farming technologies are improving ways of getting food, interest in nontimber forest products is also increasing rapidly (Kilchling et al., 2012; Schaafsma et al., 2012; Shackleton and Shackleton, 2004). For that reason, the European Union has financed the production and commercialization of nontimber forest products in some Central Africa countries (Cameroon and DR Congo) through the Food and Agricultural Organisation (FAO) in partnership with the Centre for International Forestry Research (CIFOR), the World Agroforestry Center (ICRAF) and the Netherlands Development Organisation (SNV) (FAO, 2012). Indigenous knowledge systems are considered to be tuned to the needs of local people and the quality and quantity of available resources (Pretty and Sandbrook, 1991).

Generally, in rural areas, the duty of picking and harvesting non-timber forest products appears to be related to women. It is done with special care since nature produces toxic as well as nontoxic non-timber forest products. The inedible non-timber forest products are sometimes very toxic and can decimate an entire population of consumers. Misidentification of inedible species has led to several cases of poisoning because of the highly toxic compounds (Soldo, 2007; Broussard, 2001), such as Amanita toxins, capable of provoking various symptoms from slight gastrointestinal discomfort to death.

In the DRC, the biodiversity of rainforests offers a variety of species (Mukinzi et al., 2005; Amori et al., 2011) with high similarity, to the extent that even the well trained persons can easily misidentify inedible non-timber forest products. Although biodiversity is spread countrywide, this study targeted bioindicators of toxicity from three western provinces named Bandundu, Bas-Congo, and Equateur. With plenty of watershed and landscape, these provinces have a high similarity of the biodiversity. To the best of our knowledge, this study is the first to address the indigenous knowledge related to picking up and harvesting of no-timber forest products in the western part of the DRC. 


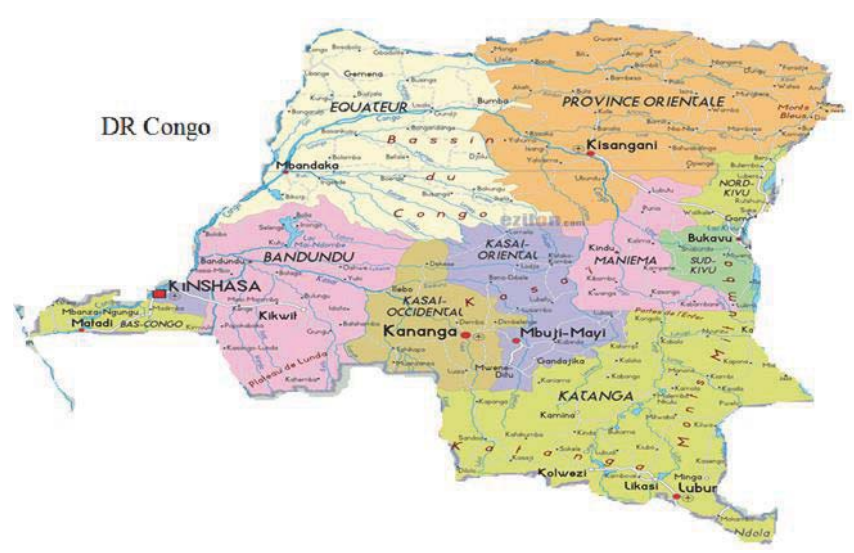

Figure 1: Map of the DR Congo

\section{Research Methodology}

A "general interview guide approach" was used for collecting data (information) from each of the twelve (12) randomly selected interviewees (women) of different ages and backgrounds in Kinshasa, the capital city of the DRC. The general interview guide approach focused on the collection of mushroom, fruits, wild vegetable and firewood as non-timber forest products. Questions related to the above non-timber forest products included information on: the substrates on which mushrooms grow, training (in the field or at home, if any) for collection, prior observation before picking or collecting the products, evidence of the non-toxicity of the non-timber forest products and their recognition. Initiation about guidelines for identifying nontoxic non-timber forest products is normally done either by questions-and-answers in evening around the fire or by a careful observation of living beings (bio) as indicators (bioindicators) in the forest, in case of suspicion. The characteristics of the interviewees are presented in Table 1 to 5.

Provinces of origin, age (not less than 20 years), and time spent in the rural area (not less than 20 years) collecting non-timber forest product were the major criteria of selecting the interviewees. In addition, education level was assessed as a factor that could influence responses of the interviewees.

Feshi, Bulungu, and Masimanimba (in Bandundu), Tshela and Luozi (in Bas-Congo), and Bumba and Mbandaka (in Equateur) are the territories where the interviewees spent most of their life before relocating into Kinshasa. The provinces of Bandundu, Bas-Congo, and Equateur were selected because of the major role they play in supplying nontimber forest products (wild vegetable, game meat, fruits, mushrooms and firewood) into Kinshasa. Bila-Isia et al. (2013) reported that the ecosystem of the western (Bandundu, Bas-Congo, Equateur) contains areas of permanently flooded swamp forest, seasonally flooded swamp forest, and flooded grassland. The permanently flooded swamp forests are home to extensive biodiversity, which has not been disturbed very much by outside influences. It also forms one of the largest continuous areas of freshwater swamp forest in the world. Table 1 shows the origin of the interviewees.

Table 1: Interviewees' provinces of origin

\begin{tabular}{lc}
\hline Province of origin & Number \\
\hline Bandundu & 5 \\
Bas-Congo & 4 \\
Equateur & 3 \\
\hline
\end{tabular}

This study estimated that at 20 years old a lady was mature enough and capable to be interviewed for this specific investigation. The age interval of the interviewees is reported in Table 2.

Table 2: Age range of the interviewees

\begin{tabular}{lc}
\hline Age (years) & Number \\
\hline 20 to 39 & 3 \\
40 to 59 & 6 \\
More than 60 & 3 \\
\hline
\end{tabular}


The investigation of responses could not depict any correlation between ages, marital status or the time of relocation into the capital city and the indigenous knowledge of interviewees on the collection of non-timber forest products. Table 3, 4, and 5; however, disclose the education level, marital status, and duration of interviewees since they relocated into Kinshasa, respectively.

Table 3: Education level of the interviewees

\begin{tabular}{lc}
\hline \multicolumn{1}{c}{ Education level } & Number \\
\hline None & 3 \\
Primary school & 2 \\
High school & 7 \\
\hline
\end{tabular}

Table 4: Marital status of the interviewees

\begin{tabular}{ll}
\hline Marital status & Number \\
\hline Single & 2 \\
Married & 8 \\
Widow & 2 \\
\hline
\end{tabular}

Table 5: Duration since the woman left the rural area

\begin{tabular}{lc}
\hline Duration since the woman left the rural area & Number \\
\hline 5 to 10 & 2 \\
11 to 20 & 7 \\
More than 20 & 3 \\
\hline
\end{tabular}

\section{Finding and Discussion}

\subsection{Indigenous knowledge}

Indigenous knowledge encompasses three processes: empirical observation, traditional teachings, and revelation (BrantCastellano, 2000) which have been passed down through generations. The most known indigenous knowledge for identifying non-timber forest food is the "folk knowledge", which refers to an everyday, commonsense understandings accumulated through ordinary human experience (Maiese, 2005). For years, the knowledge and wisdom of the wise and cunny women considered invaluable for the wellbeing of different communities has been transferred through generations. Considered as a wealth, wisdom is handed down from ancestors to the youth. This is especially important for women who must "bear" the community's life by making a living form the forest.

\subsection{Bioindicators}

Bioindicators are organisms or communities of organisms, whose reactions are observed representatively to evaluate a situation, giving clues for the condition of the whole ecosystem (Foissner, 1999). They include species or communities and are used to assess the quality of the environment and how it changes over time (Figueira et al., 2009). Bioindicators play an important role in monitoring toxicity containing leaves, mushrooms or fruits; even firewood in many communities. Scientifically, biomonitoring has been around since 1908 when a paper was published on the use of macro invertebrates to assess water quality and degrees of pollution in rivers subject to sewage contamination (Gerhardt, 2002). Nowadays, Gerhardt reports that bioindicators are useful for three situations: 1) where the indicated environmental factor cannot be measured, 2) where the indicated factor is difficult to measure, and 3) where the environmental factor is easy to measure but difficult to interpret.

Indigenous knowledge of the Congolese rural community, perhaps even of other people across the world, on bioindicators of toxicity of non-timber forest foods might be dated back to the time since the existence of the human race. It is based on proper observation of the living beings on, around, or even eating the edible non-timber forest product. Interviews conducted with women, in Kinshasa, revealed that wildfowl, caterpillars and locusts, millipedes, monkeys, and domestic fowls (cocks and hens) are used as bioindicators of toxicity by the majority of the communities. The interview 
approach permitted the collection of data that could be grouped as follows:

\subsubsection{Birds (wildfowls) and Monkeys}

Generally, birds and monkeys feed on wild fruits. Logically, if eating specific wild fruits is not harmful to birds and monkeys, the indigenous knowledge assumes that the fruits should be edible by humans. Therefore, the indigenous knowledge states that before collecting any fruit in the forest, a careful observation of traces of edibility by the above animals should be noticed (presence of many birds around the fruits, pecking fruits or monkey eating the fruit).

\subsubsection{Caterpillars and locusts}

Several types of caterpillars and locusts are highly nutritious and used by humans as sources of animal proteins. These insects feed on leaves. According to the interviewees, most wild leaves on which edible insects feed are considered as edible by humans. This knowledge has saved many people life. This cannot be more emphasized because even scientific studies (Sundov et al., 2005) have reported that misidentification of wild leaves as vegetables or spices can be fatal.

\subsubsection{Millipedes}

Harmless millipedes (to humans) and other arthropods, such as: centipedes, woodlice (sow bugs), and pill bugs are sometimes found surrounding mushrooms where they are seeking for a specific microclimate or food. Therefore, the interviewees assumed that the presence of these macro-invertebrates indicates that the specific mushroom around which the insects are found is not toxic, probably edible and allows collection for the table. This is understandable because, in their studies, Kappes et al. (2007) and Cébron et al. (2011) reported that soil chemical composition contributes to biotic (e.g. woodlice and millipedes) stress in forest ecosystems.

\subsubsection{Free range chickens (traditional poultry)}

In rural areas, free range chickens have a tendency of occupying and spreading dust, within their feathers, from extinguished fireplaces, especially in dry season. This practice is probably done to heal/prevent skin infections (e.g. nodular skin lesions, abnormal growth of skin) or external parasites (e.g. mites and lices). On the other hand, it is known that combustion of firewood generates a wide range of toxic and nontoxic substances (Gaeggeler et al., 2008). It can be understood that an extinguished fireplace respelling domestic fowls is an indication of toxicity. Therefore, the firewood used has produced toxic substances which the birds cannot bear and are surely toxic to human. People will then be warned, by this knowledge, not to collect those spices next time as firewood otherwise, they will bring diseases home. Scientifically, free range chickens are also used as bioindicators of pollution (Pirard et al., 2003).

\section{Conclusion}

This paper carried out an investigation which has reported the use of living beings (bioindicators) as guides for the collection of non-timber forest products. The investigation showed that rural communities house a lot of knowledge so called "Indigenous knowledge" which, over the years, has sustained people's life. Such "Indigenous knowledge" can scientifically be exploited to study natural phenomena. Also, it can underpin research and prevent unnecessary basic exploration. Further investigations, therefore, are suggested to understand practices and knowledge that have been driving the sustainability of live in remote area preventing them from different natural disasters or incidents.

\section{References}

Amori, G., Chiozza, F. \& Rondinini, C. (2011). Country-based patterns of total species richness, endemicity, and threatened species richness in Africa rodents and insectivores. Biodivers Conserv., 20, 1225-1237.

Bila-Isia, I., Mafuta, N., Lisalama, W., and Mbende, L. (2013). Elephant effect on forest physical structure and plant species composition in Salonga and Malebo (Lac Tumba landscape), Democratic Republic of Congo. Pachyderm, 53, 28-37.

Brant-Castellano, M. (2000) Updating aboriginal traditions of knowledge. In G. Dei, B. Hall, \& D. Rosenberg (Eds), Indigenous knowldges in global contexts (pp. 21-36). Toronto, Canada: University of Toronto Press

Broussard, C.N., Aggarwal, A., Lacey, S.R., Post, A.B., Gramlich, T., Henderson, J. M. \& Younossi, Z.M. (2001). Mushroom poisoningfrom diarrhea to liver transplantation. The American Journal of Gastroenterology, 96, 3195-3198. 
Canadian Forest Service (2007). Forest conditions, monitoring, and reporting glossary, Natural Resources Canada, Ottawa, Ont. [Online] Available: http://cfs.nrcan.gc.ca/terms/browse/N (January 22, 2013)

Cébron, A., Cortet, J., Criquet, S., Biaz, A., Calvert, V., Caupert, C., Pernin, C., Leyval, C. (2011). Biological functioning of PAH-polluted and thermal desorption-treated soils assessed by fauna and microbial bioindicators. Research in Microbiology, 162, 896-907.

FAO (2012). Mobilisation and capacity building for SMEs involved in the production and commercialisation of non-wood forest products in Central Africa. [Online] Available: http://www.fao.org/forestry/enterprises/nwfp-centralafrica-eu/en/ (May 23, 2013)

Figueira, R., Tavares, P.C., Palma, L., Beja, P., Sérgio, C. (2009). Application of indicator kriging to the complementary use of bioindicators at three trophic levels. Environmental Pollution, 157, 2689-2696.

Foissner, W. (1999) Soil protozoa as bioindicators: pros and cons, methods, diversity, representative examples, Agriculture. Ecosystems and Environment, 74, 95-112.

Gaeggeler, K., Prevot, A.S.H., Dommen, J., Legreid, G., Reimann, S., Baltensperger, U. (2008). Residential wood burning in an Alpine valley as a source for oxygenated volatile organic compounds, hydrocarbons and organic acids. Atmospheric Environment, 42 , 8278-8287.

Gerhardt, A. (2002). Bioindicator species and their use in biomonitoring Environmental Monitoring I. Encyclopedia of Life Support Systems (EOLSS), Developed under the Auspices of the UNESCOEolss Publishers, Oxford.

Kappes, H., Catalano, C., Topp, W. (2007). Coarse woody debris ameliorates chemical and biotic soil parameters of acidified broadleaved forests. Applied Soil Ecology, 36, 190-198.

Kilchling, P., Hansmann, R. \& Seeland, K. (2009) Demand for non-timber forest products: Surveys of urban consumers and sellers in Switzerland. Forest Policy and Economics, 11, 294-300.

Maiese, M. (2005), "Theories of Knowledge." Beyond Intractability. Eds. Guy Burgess and Heidi Burgess. Conflict Research Consortium, University of Colorado, Boulder. [Online] Available: http://www.beyondintractability.org/bi-essay/knowledge-theories (January 22, 2013)

Mukinzi, I., Katuala, P.G.B., Kennis, J., Gambalemoke, M., Kadange, N., Dudu, A.M., Colyn, M. \& Hutterer, R. (2005). Preliminary data on the biodiversity of rodents and insectivores (Mammalia) in the periphery of Kisangani (D R Congo). Belg. J. Zool., 135 (supplement), 133-140.

Pirard, C., Focant, J.F., Massart, A.C. and De Pauw, E. (2003). Measurable impact of an old MSWI on the level of dioxins in free-range chickens and eggs grown in its vicinity. Organohalogen Compounds, 64, 158-161.

Pretty, J. and R. Sandbrook, 1991. "Operationalising Sustainable Development at the Community Level: Primary Environmental Care." Paper presented at the DAC Working Party on Development Assistance and the Environment, London, October 1991.

Schaafsma, M., Morse-Jones, S., Posen, P., Swetnam, R.D., Balmford, A., Bateman, I.J., Burgess, N.D., Chamshama, S.A.O., Fisher, B., Green, R.E., Hepelwa, A.S., Hernández-Sirvent, A., Kajembe, G.C., Kulindwa, K., Lund, J.F., Mbwambo, L., Meilby, H., Ngaga, Y.M., Theilade, I., Treue, T., Vyamana, V.G. \& Turner, R.K. (2012). Towards transferable functions for extraction of Nontimber Forest Products: A case study on charcoal production in Tanzania. Ecological Economics, 80, 48-62.

Shackleton, C.M. \& Shackleton, S.E. (2004). The importance of non-timber forest products in rural livelihood security and as safety nets: a review of evidence from South Africa. South African Journal of Science, 100(11 \& 12), 658-664.

Soldo I, Kucan Z, Timarac J, Mihaljević I, Matijević M, Perić L, Lisnjić D, Sesar Z, Kadojić D, Vcev A. \& Mićunović N. (2007). Mushroom poisoning. Coll Antropol., 31(4), 1099-103.

Sundov, Z., Nincevic, Z., Definis-Gojanovic, M., Glavina-Durdov, M., Jukic, I., Hulina, N., Tonkic, A. (2005). Fatal colchicine poisoning by accidental ingestion of meadow saffron-case report. Forensic Science International, 149, 253-256. 